When first seen it was half way between Capella and $a$ Persei ; it passed in a slightly curved direction, which was concave towards Auriga, downwards to a line joining $\beta$ and $\alpha$ Tauri, disappearing at a point one-third of the distance from $\beta$ towards $\alpha$. It was very much brighter than Jupiter, and quite half the diameter of the moon; I made these comparisons immediately after it had passed.

Its passage occupied about eleven and a half seconds, and it left a bright continuous yellow streak in its wake, which did not fade until about two or three seconds after the meteor had disappeared; this enabled me the more readily to fix its position. The whole of its path was not seen, as it emerged from behind a tree with thick foliage, though its light attracted my attention before the meteor appeared.

It was pear-shaped, and its brightness appeared to slightly increase; its colour was a very bright reddish yellow changing to deep purple at its disappearance; it was not followed by any noise. The latitude of place of observation is N. $51^{\circ} 28^{\prime} 2 \mathrm{O}^{\prime \prime}$, the longitude W. $0^{\circ} 20^{\prime} \mathrm{I}^{\prime \prime}$.

C. Thwaites

Isleworth, September 2I

\section{EVOLUTION AND FEMALE EDUCATION}

$\mathrm{NE}$ of the most remarkable features of the advance of science is perhaps the increasing facility afforded for bringing under the grasp of physical treatment questions formerly thought to be within the range of abstract reasoning alone. These two methods, if correct, will of course run parallel to each other, and at the same time tend reciprocally to confirm their truth:-the physical method being often the more easily followed, and therefore perhaps considered on that account the more certain of the two. Many instances may no doubt readily present themselves of conclusions formerly reasoned out on abstract grounds (more especially by the ancient philosophers), and subsequently confirmed by physical reasoning. As a modern example of this double treatment of the same subject we might mention the very important question of the higher mental training of women, dealt with by the late John Stuart Mill on substantially abstract grounds, and touched on by the theory of evolution on physical grounds. As we propose solely to notice the physical side of the question here, perhaps this brief essay may not be thought unsuited to the columns of NATURE. We do not expect to bring forward anything especially new, but we may perhaps exhibit the case in some novel aspects; at the same time we may avoid elements of uncertainty by carefully separating the facts supported by scientific evidence from the question of the desirability or undesirability of the measures to be taken upon these facts as a basis, and thus the paper may hope to attain that degree of reliability or solidity which is usually looked for in a journal of natural science.

Perhaps the most valuable characteristic of the doctrine of evolution (or the history of the past rise of man) is the lesson it gives for future progress. It will be apparent that an inquiry into the conditions affecting the progress of mankind would want one of its primary elements if the conditions bearing on the advancement of woman (as one half the race) were excluded therefrom; and the fact of this point being popularly underrated may be considered as rather in favour of its value and significance than not, inasmuch as all great reforms consist in the conquest of popular prejudice. That the value attached to this reform by Mill, which occupied a great part of his life, was not overestimated by him will, we think, become all the more evident when the subject is brought under the test of the theory of evolution.

Mr. Darwin in his work, "The Descent of Man" (second edition), remarks :- "It is indeed fortunate that the law of the equal transmission of characters to both sexes prevails with mammals, otherwise it is probable that man would have become as superior in mental endowment to woman as the peacock is in ornamental plumage to the peahen" (p. 565).
This therefore puts the question of the education of woman in a somewhat new light: though in a light probably suspected by some (including, it may be said, the writer) beforehand, on abstract grounds. For this would show, on a reliable physical basis, that one of the chief arguments for the intellectual training of woman must be for the direct benefit of man. For the above deduction, grounded on the evidence of natural science, would indicate clearly that man, by opposing the intellectual advance of woman for countless generations, has enormously injured his own advance-by inheritance. In other words, while man has been arbitrarily placing restrictions in the way of the mental progress of woman, nature has stepped in, and by the laws of inheritance has (to a large extent) corrected, at his expense, the injury which would otherwise have been inflicted, and which, without this interposition of natural law, would have made itself transparently obvious, centuries ago. Man, by hindering woman from performing her natural share in the work of brain development, has been compelled by nature to do the work for her, and valuable brain tissue (accumulated by mental discipline), which would have been man's own property as the fair reward of intellectual labour, has gone over by the rigorous laws of inheritance ${ }^{x}$ to the female side, to fill up the gap artificially created by man through his persistent hindrance of woman from doing her part in the progressive development of the brain. The probable extent of the gap by accumulation (from all causes, including the very important factor of man's obstruction) is apparently roughly indicated by the comparison employed in the above quotation. It would seem, therefore, that it could scarcely be said to be altogether fortunate (in one sense at least) that "the law o equal transmission of characters to both sexes prevails with mammals ; "for this fact has served to conceal an evil which in reality exists in all its magnitude, and which otherwise it would not have required the intellect of a Mill to detect, but which must have become glaringly apparent long ago. Physical science would therefore appear to show a remarkable confirmation of Mill's magnificent theoretic analysis, and of the reality of those evils, the clear exposure of which by him looked to some like exaggeration. In fact it would result from the scientific evidence that however monstrously women might have been treated, however much idleness might have been enforced, or healthy brain exercise prevented, nature would have infallibly corrected the irregularity at the expense of man, entailing of course the partial extinction of the progress of the race (as a whole). Possibly the not uncommon popular ridicule which (at first, at least) accompanied Mill's protests, the conceited independence of some men in ignoring the fact that they are descended from women, and their failure even now to realise so obvious a truth as the desirability of clearing away all obstacles to the intellectual advance of woman (by facilitating education, by removing the bars to healthy exercise of the brain in suitable professions, \&c., in place of idleness) may itself be in part a consequence of the deficiency of brain tissue caused by the drain through inheritance which goes to counteract their efforts of obstruction. Some of the reasons urged against the higher mental training of woman are of so superficial a character as themselves to show the extensive magnitude of the evil. One notoriously not uncommon ground adduced

$x$ Possibly (and we believe this may have been suggested by others) the less stability, or sometimes almost hysterical character of the female intel. lect may be naturally due to the brain qualities being gained mainly by inheritance instead of by hard practice, as in the case of man's brain attributes. While the faculties of man have acquired the steadiness produced by centuries of healthy intellectual discipline and exercise, the field for this has been closed to woman to a large extent. In fact the scientific evidence would appear to show that the common brain (i.e. the brain common to the race) has been built up mainly by man's efforts, while woman has to a great extent inherited her share at his expense, though no doubt if left entirely unfettered she would have largely contributed to the common good; and it may be inferred with tolerable safety that the race would then have been elevated far above its present status. 
is that women already are, as a rule, somewhat inferior in mental power to men, forgetting that they were precisely made inferior by the obstacles thrown for centuries in the way of their advance (some of these specially fixed by legal enactment), and which are sometimes of such a kind as almost to amount to a tax on liberty. It may well be conceivable that the law of inheritance, though it has achieved a vast amount, may not have been able to combat these artificial conditions for producing inferiority with entire success. The above plea of existing inferiority in mental power, therefore, so far from being an argument against female education, ought, when justly viewed, to be regarded as the strongest reason the other way. For if obstruction has produced--in spite of the powerful countervailing influence of the law of inheritance-a certain degree of inferiority: so (conversely) by equally reliable casual sequence encouragement would produce an effect in the opposite direction. Moreover, preciscly on account of the fact that woman is already somewhat handicapped by nature in the race of progress, would there be all the more reason why every encouragement should be given; $\dot{a}$ fortiori, all artificial hindrances in the way of advancement removed. It would be a great mistake if the idea were for one moment entertained that progress can be accomplished by letting matters generally drift under the influence of prevailing custom. If there is one thing more certain than another it is that man can never hope to progress with satisfactory rapidity without having a sharp eye to the conditions necessary for this object, and examining (by the light of reason and knowledge gradually acquired) all his customs, to see if they are desirable or not. To facilitate this end the history of past progress, unfolded in the theory of evolution, may afford some valuable instruction. The increasing appreciation of the value of co-operating with the weak, instead of domineering over them, may be perhaps regarded as one of the most plcasing accompaniments to the advance of science.

S. TOlver PRESTON

THE YANG-TSE, THE YELLOW RIVER, AND THE PEI-HO

$\mathrm{T}$ HESE three rivers form conjointly the great riversystem of China. Although at the present day each of them runs its separate course to the sea, there is good reason to belicve that several centuries since they were united by a number of connecting branches in a manner somewhat resembling the junction of the Ganges and the Brahmapootra in our own time. Such is the inference to be drawn from an ancient Chinese map copied by Alvarez Semedo, a Portuguese Jesuit, and which must be assigned to a time preceding that of the construction of the Grand Canal by Ghenghis Khan in the beginning of the thirteenth century." Linked together as these rivers were in the past, a brief consideration of their present condition will prove that they are labouring towards the same end in our own day. But before proceeding to examine them in their conjoint character, it will be necessary to consider briefly their leading bydrological features.

I. The Yang-tse-the largest and most important of these thrce rivers-has a course of about 3,00o miles, and drains an area which is variously estimated between 750,000 and 550,000 square miles : for my own calculations I will adopt the mean of these two estimates, namely,

${ }^{x}$ The author, Surgeon H. B. Guppy, of H.M.S. IIornet, writing from Yokohama, February 1x, says:- "I forward to you by this mail a paper containing the results of observations I have made during the last two years on the sulject of the Yang-tse and the Pei-ho, together with similar information as regards the Ycllow River. Iooking on these three rivers as in reality one river-system, I have embodied in one paper all the data concernin I can answer for the accuracy of the various estimations, and have employed i can answer for the accuracy of the vari

the usual methods in obtaining them." River," published in the Geographical Magazine for April, 1878 .
650,000 square miles. Its waters, commencing to rise in February and March, reach their highest level in the month of June or July; and here they remain with occasional fluctuations till the end of August or the beginning of September, finally reaching their lowest level towards the close of January.

With regard to the discharge of water of this river, Capt. Blakiston ${ }^{1}$ has estimated the average amount carried past T-chang, which is situated at about 960 miles from the sea, at 500,000 cubic feet per second; he founded this estimate on observations made during the months of April and June. When stationed at Hankow in the winter $1877-78$, a place distant about 600 miles from the sea, I set to work to make a similar estimate of the water carried past that city for the twelve months included between May 1877 and May I878. Having taken a line of soundings across the river and having ascertained the river's breadth ( 1,450 yards, by sextant measurement) at a point below the union of the Han with the main stream, I commenced a series of observations on the rise and fall of the river water and on the force of the current, which, combined with information received from the Customhouse and from other sources, supplied me with the necessary data for my calculation. The results are contained in the following table:-

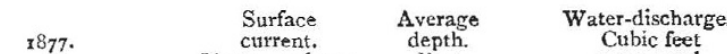

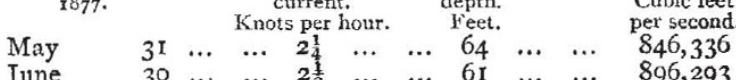

$$
\begin{aligned}
& \begin{array}{llllllllllr}
\text { June } & 30 & \ldots & \ldots & 2 \frac{1}{2} & \ldots & \ldots & 61 & \ldots & \ldots & 896,293 \\
\text { July } & 31 & \ldots & \ldots & 3 & \ldots & \ldots & 58 & \ldots & \ldots & \text { r, 022, } 656
\end{array}
\end{aligned}
$$

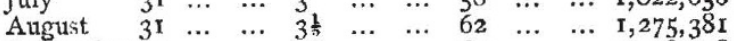

$$
\begin{aligned}
& \begin{array}{lllllllllll}
\text { September } & 30 & \ldots & \ldots & 2 \frac{3}{4} & \ldots & \ldots & 63 & \ldots & \ldots & \text { 1, } 018,248
\end{array}
\end{aligned}
$$

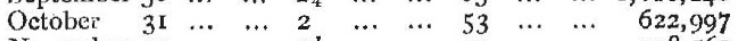

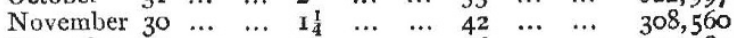

$$
\begin{aligned}
& \begin{array}{lllllllllll}
\text { December } & 31 & \ldots & \ldots & \text { I } & \ldots & \ldots & 36 & \ldots & \ldots & 21 \mathrm{I}, 584
\end{array} \\
& \text { ז878. } \\
& \text { January } \\
& \text { February } \\
& \text { March } \\
& \begin{array}{lllllll}
3 \mathbf{I} & \cdots & \cdots & \frac{4}{5} & \cdots & \cdots & 30
\end{array} \\
& \text { 30 } \quad \cdots \quad \cdots \quad 141,085 \\
& \text { April } \\
& 31 . \\
& \text {... } \\
& \ldots . \\
& 30 \\
& \cdots \\
& \text { … } \quad \cdots \quad 45 \\
& \text { … } 5 \\
& \begin{array}{l}
39 \\
45 \\
57
\end{array}
\end{aligned}
$$

We may therefore place the average water-discharge for the year at Hankow at 650,000 cubic feet per second. Now, estimating the area of drainage above Hankow to be about 11 of the whole area, and assuming that the portion of the Yang-tse valley below Hankow drains off its waters at the same rate as the remainder of the riverbasin, it follows that the average water-discharge for the whole river may be placed at 770,000 cubic feet per second.

With reference to the amount of sediment carried by the Yang-tse past the same city, I found as much as seven grains in the pint (nearly one drachm in the gallon) in the month of July, when the river was at its height; while in March, when the river was low, I found as little as three-fifths of a grain per pint. The average proportion of sediment during the twelve months in question I estimate at four grains in the pint (a little over half a drachm per gallon). This represents a proportion of $\frac{1}{2188}$ by "weight," or (taking the specific gravity of the dried mud at 1 .9) of ${ }^{1}$ " by "bulk" of the average discharge of water. It is thus easy to obtain the total amount of sediment carried during the twelve months past Hankow, namely, $4,945,280,250$ cubic feet : but to allow for the amount of mud a river pushes along its bed, one-tenth must be added according to the principle laid down by Messrs. Humnhreys and Abbot in the case of the Mississippi. This will bring the total anmual discharge of sediment at Hankow up to 5,439,808,275 cubic feet, or at the rate of 172 cubic feet per second. Now, assuming that the drainage area below Hankow sup× "Five Months on the Yang-tse." 